This item was submitted to Loughborough's Research Repository by the author.

Items in Figshare are protected by copyright, with all rights reserved, unless otherwise indicated.

\title{
The evolution of migration management in the global north
}

\section{PLEASE CITE THE PUBLISHED VERSION}

https://www.routledge.com/The-Evolution-of-Migration-Management-in-the-Global-

North/Oelgemoller/p/book/9781138185340

\section{PUBLISHER}

Routledge

VERSION

AM (Accepted Manuscript)

\section{PUBLISHER STATEMENT}

This work is made available according to the conditions of the Creative Commons Attribution-NonCommercialNoDerivatives 4.0 International (CC BY-NC-ND 4.0) licence. Full details of this licence are available at: https://creativecommons.org/licenses/by-nc-nd/4.0/

\section{LICENCE}

CC BY-NC-ND 4.0

\section{REPOSITORY RECORD}

Oelgemoller, Christina. 2017. "The Evolution of Migration Management in the Global North". Loughborough University. https://hdl.handle.net/2134/24656. 


\section{Word count: 13.401}

\section{Introduction}

Today, all of us are supposed to be 'included' in a totality that is defined in consensual terms as an addition of groups each regarded to have its own identity. (Rancière, 2001: 348)

Since the 1970s, concern about international migration has moved from the realm of low politics into the realm of high politics: the reaction in the Global North to international migration was to both hyper-politicize it and depoliticize it simultaneously. On the one hand, politicians, the media and increasingly nationalist right-wing groups enabled a disproportionately vicious and paranoid discourse about the mobility of so-called illegal migrants. On the other hand, governments withdrew in their effort to keep their policy making as invisible as possible. However, neither reaction to international migration questioned the presumption of sovereignty and the legitimacy of states to restrict international migration (Opeskin, 2012; for exceptions see Dowty, 1987; Gibney, 1988), and with that, the mantra that migration was a global challenge for which a solution was to be found. This has given rise to a pervasive discourse around the management of migration.

This book queries the geopolitics of migration that the Global North imposes under the name of Migration Management. In this book, questions are asked about the conditions of possibility for the formation of the doctrine of Migration Management as well as its logic and argues that Migration Management is an instance of normative violence - meaning a violence of particular norms that prescribe who can be of ac/count and who cannot imposed by governments of the Global North. Crucially this sorting is done in spaces outside of what is widely understood as internal sovereignty. 
Migration Management is based on spatio-legal assumptions of state sovereignty and interdependence, a knowledge that exists through differentiation based on assumptions about people and cultures and the legitimacy of access.

Put differently, Migration Management is a particular form of representation, of knowledge production, that is constitutive of a particular kind of order spatially organized and underpinned by power relationships. These power relations are claimed to be democratic, since those states of the Global North which participate in the doctrine formation and maintenance of Migration Management are all ordered based on roughly similar forms of popular representation and administration. However, Migration Management is based on statecraft, ${ }^{1}$ which formulates truth claims that are formative of discourse as a linguistic structure of meaning that establishes and legitimizes hierarchies and domination. In our contemporary moment and '[...] being constituted out of $[\ldots]$ the forces of history, the sovereign state can only transpose [...] to a new sphere of political reality: the international system’ (Bartelson, 1995: 243). Today, our contemporary moment is known as interdependence; as a consequence, '[...] modern sovereignty is profoundly paradoxical, since it contains both a prophecy of interstate anarchy and a promise of cosmopolitan redemptions in which the international itself vanishes [...]' (Bartelson, 1995: 244).

Visible markers of this phenomenon are the dead bodies of people from the Middle East, Africa or Asia found in the Mediterranean Sea. On 6 April 2011, the then EU Commissioner Cecilia Malmström, responsible for Home Affairs, wrote a blog as follows:

A boat from Libya sank this morning in the Mediterranean with 265 people on board. So far only 48 have been rescued. The latest information we've received is that 20 bodies have now been found and that the search is ongoing. 
It is awful that criminal networks exploit vulnerable people and make money on smuggling them to Europe. [...]

In order to minimise the risk of people drowning in the Mediterranean a longterm effort is needed, including close cooperation with the countries in the region. [...]

At the same time, the right of people fleeing persecution or violent conflict to seek asylum must be guaranteed. People in such a situation should be given protection wherever they seek it, and I am very grateful to the authorities, international organisations and NGOs in Tunisia and Egypt who are making such great efforts to host the many refugees who have been fleeing Libya in recent weeks. I have also asked the EU's Member States to make a gesture by agreeing to resettle some of them here in Europe. http:

//blogs.ec.europa.eu/malmstrom/tragedy-in-the-mediterranean/ viewed June 2011

Only four years after this event the year 2015 saw a staggering rise in those dying at sea and, more important from the perspective of the countries of the European Union, those arriving - on foot - on European territory. In 2015 the majority of people came from Syria, as Egypt and other countries in the region which had so generously hosted many mobile and displaced people, including Syrians, are so battered by violent conflict that people chose to leave in order to find safety and a chance to rebuilt their lives.

In this introduction I will first briefly outline what I see to be the problem underlying the argument stated above, namely that international migrants die seemingly as a result of the doctrine the Global North develops and the external policies it implements motivated by maintaining the integrity of the system, rather than a concern for the integrity of the person. I will then outline the contested character of this knowledge and in a further step show how this knowledge is historical. In a next step I will offer a brief discussion concerning the significance of approaching international migration differently, which is followed by an outline of the framing of this book. Finally I will introduce the road map which the book follows in order to elaborate the argument. 


\section{International migration and the integrity of the system}

The presumption of sovereignty has two interrelated consequences. First, it leads to claims about democracy - understood today as effective governance for a specified, territorially bounded community - which justifies hierarchy, authority and, ultimately, domination. Sovereignty claims to constitute a juridico-political body politic and a technique of government understood as administrative management which is legitimate, so the claim goes, because it is founded on democratic principles of equality and self-government. Second, and underlying the above, it leads to claims about territory and, with that, particular representations and practices of bordering. Hence, whilst international migration is commonly framed as a problem of reception and integration because of illegitimate breaches of sovereign territory, governments of the Global North find themselves participants in a context where global interdependence seems to demand governance beyond the nation-state. Squire (2009) shows eloquently in her work how these claims are problematic with a focus on internal sovereignty and in particular exclusion from civil participation. Adding to this important critique I want to focus on inconsistencies and effects referring to external sovereignty. The control of frontiers - those boundaries which grant or deny access - is part of the founding narrative of nation-states as bounded sovereign territories encompassing a people who are deemed legitimate political subjects, all with a place and function in the society that the border delimits. Freedom of movement contradicts control. If policy making reaches out beyond the state, then it is only logical that democracy needs to do so also.

Interdependence, the expression of the globalized neoliberal consensus, encompasses the combination of free market economics and the security state (Newman, 2007a). Consensus here does not refer to agreement of all about a policy. It means 
'the government practice and conceptual legitimization of a democracy after the demos, a democracy that has eliminated the appearance, miscount, and dispute of people, and is thereby reducible to the sole interplay of state mechanisms and combinations of social energies and interests' (Rancière, 1998: 101-102).

Politics, in other words, is dismissed - there is no reasonable alternative to consensusdemocracy. The condition of possibility for such polarization between either being economically productive or a security threat, in the case of people's mobility across borders, is the neoliberal consensus, or, as Rancière (1999) puts it, consensusdemocracy. It is an order of reason developed since the 1970s. It introduces a rationality that transforms the world according to an image of the economic that is 'tasked with securing, improving and leveraging [neoliberal consensus'] competitive positioning and with enhancing [every person’s] (monetary and non-monetary) portfolio value' (Brown, 2015: 10): the homo oeconomicus of the twenty-first century. The impact for migrants is significant. If a migrant has an adequate portfolio that conforms to the standards set for access, this person will be included. If, however, the migrant does not, this person will be excluded - often violently.

One of the ordering devices of consensus-democracy is the rule of law; it instrumentalizes law as formal, proliferated, complexified and expanded legalism in which the focus is on process rather than substance in the name of government as management. There is a firm belief among governments, in particular European governments, that the nature of international migration is a threat to the stability of their nation-states, ${ }^{2}$ because control over the regulation of migration is lost and this control needs to be regained. This is particularly so, it is argued, where it concerns the seeking of asylum - when people move without a legible and competitive portfolio, when they arrive uninvited, when they make a claim for freedom and equality without 
having formal juridico-political status. This raises questions about the historical assumptions of discourses of control.

Implicit in the imagination of European governments is the assumption that migration has been 'under control' at some point in the past and that it is possible to control the movement of people across borders, providing the systems of Migration Management applied are efficient. This assumption is both important and erroneous in its mirroring of unquestioned sovereignty claims. It is important, because it makes visible what drives and undermines policy makers in their efforts to manage migration. It is erroneous, for the simple reason that international migration is - legally and sociologically - constitutively necessary for a state to be possible and to claim sovereignty. The migrant signifies what is proximate and, at the same time, remote; in this way the migrant validates membership (Thomas, 2013) and with it the state as the body to award membership with legal implications, justifying territorial boundaries of this juridico-institutional arrangement.

Migration Management is expressed as an all-encompassing approach. Yet observers have noted that this all-encompassing approach finds its most vivid performance as ‘external migration relations’ (Hampshire, 2015). The condition of possibility for such external migration relations is the Schengen agreement of 1985. It established the principle of freedom of movement for individuals within the European Community. As a consequence it also defined new external boundaries. In so doing the member states of the European Union are regulating a different kind of territoriality to that traditionally understood in the idea of sovereign state. Conceptualizing the individual and the state analogically is a crucial justification for sovereignty - the state is defined in this orthodox view by autonomy and entitled to self-preservation based on formulations of individual sovereignty. This was the 
starting point for governments in the early 1980s. States are defined as composed of a distinct (albeit already diverse) community within which the state confers rights anchored institutionally and territorially. Hence, the state has the right (even if marginally limited by international law) to decide who is denied access. Who was to be entering territory legitimately was defined alongside, but as a consequence, not a focus, of doctrine formation. This logic was then scaled up in the context of the European Union.

However, the scaling-up had as a consequence a challenge to the orthodox state-based model, not only in terms of its boundaries and jurisdiction. The way that legitimate access categories were transformed also had an effect on our understanding of democratic procedures of decision making. In short, Migration Management is also an example of the hollowing-out of democracy. It is a discourse, which is multidimensional in terms of its knowledge productions, practices and social relations. Migration Management is a contemporary discourse composed of a multiplicity of narratives. For example, it makes contradictory positions such as free and efficient movement for 'knowledge migrants', alongside development aid efforts in the Global South and the securing of borders against the poor intelligible. It combines a myriad of practices, spanning the entire transnational space from creating knowledge about routes and means of travel, via border control measures, detention or integration to return movement. Equally, the forces involved in making knowledge about migration and acting on it portray unity and coherence. In the end, Migration Management essentializes. It reduces cross-border mobility to a question of access, in which the individual is either illegal or legal. This 'linguistic field' has sedimented as knowledge about international migration. Yet this coherence is contested: positionalities are very diverse including movements such as 'no one is illegal', and 
far-right activists attacking those who appear different. Migration Management is often contradictory in the sense that very different forces are brought into equivalence, the claim being that Migration Management achieves the total inclusion and management of everything to do with migration globally.

At stake for governments is not the protection of people, but the integrity of the system. The logic of the integrity of the system was first voiced by the Intergovernmental Consultations on Migration, Asylum and Refugees (IGC). Much of the discussion in the following chapters is informed by archival documents produced by or in the context of the IGC, which I will elaborate on further below. Jonas Widgren is credited with having given birth to the IGC after a decade of discussing what was in the mid 1980s perceived to be an 'asylum crisis' in Western Europe. ${ }^{3}$ The perception was that, in the multilateral context of the United Nations High Commissioner for Refugees (UNHCR) and the Council of Europe, debates about how to regulate in particular asylum mobility resulted in paralysis and were abandoned. ${ }^{4}$ The IGC was invented in order to create a private space to think about ways to regain control over the unsolicited movement of people across borders into countries of the Global North. The intention was that senior participants should be facilitated to meet within informal consultations as and when this was felt to be required in order 'to nurse the totality of mobility related issues’ (Lopez-Pozas, IGC, 19 June 1991) and to coordinate common action by establishing a common and conceptual linguistic field.

The IGC works, according to a review after twenty years of activity, based on an agreement of confidentiality which offers an opportunity for government officials to reflect in a setting where participants are not held to account for national positions, yet where they have the space at the same time to develop a common linguistic and conceptual field which supports the identification of 'best practices' without the 
adoption of these 'best practices' being binding (Johnston, 2005). What is worrying here is the utter secrecy and non-transparency in which the IGC works. Based on its working method, participants are not held to account for their personal reflections and thus are not bound by any minimum standard to uphold values such as equality and liberty to which the participant's state in a multilateral forum would be answerable.

This is not to claim that the participants of the IGC single-handedly invented Migration Management. During the 1980s many of those states today identified with the Global North, many international and regional organizations, scholarly migration experts, as well as non-governmental organizations were debating international migration as a crisis in urgent need of a solution. However, the IGC was to become 'the laboratory' (Johnston, 2005) for European states in the face of unbidden people mobility. Much of the doctrine formation can be located in the IGC as a normforming forum, circulating ideas emanating from the secrecy of debates into the more formal fora of implementation without being hampered by tedious multilateral and/or democratic debate. The IGC's reliance on informality and confidentiality as a stateowned forum aimed to formulate emerging policy issues outside of the formalized and institutionalized framework of either the international community or its conventions which were enforceable within a sovereignty-based context.

This does not mean that participants to the IGC's meetings - depending on subject matter these were senior officials or technical-level staff - actively aimed at undermining their liberal democracies. Quite to the contrary, participants felt that the political order had to be rescued from all the destabilizing effects of the time. Where democracy is anarchic in its characteristic of contingency and openness (Newman, 2005), the neoliberal consensus hollows democracy out, rather than overturning it 
(Brown, 2015). In this way, consensus-democracy converts the political character of democracy into statecraft - or management, defined by the combination of doctrine formation and technological enforcement under the control of the bureaucracy. Such conversion is based on an assumption of making evidence-based judgements free of ‘ideologically’ driven sentiments - characterized by this particular economic rationality: it de-democratizes. In consequence the secrecy and concomitant quiet insertion of policy into processes of formal enforcement also enables populistpolarizing views such as those voiced by conservative and extreme-right-leaning groupings.

\section{Migration Management as normalized but contested discourse}

The notion that '[i]nternational migration is part of a transnational revolution that is reshaping societies and politics around the globe' (Castles and Miller, 2009: 7) has been accepted by almost all migration scholars. This 'age of migration', Castles and Miller argue, arises because of several tendencies. First, globalization of migration means more and more countries are affected by human mobility. Similarly, an acceleration of international migration gives rise to the impression of 'mass migration'. Furthermore, the issue of international migration is increasingly more often on the agenda not only domestically, but transnationally.

Castles and Miller thus succinctly provide a sense of the normalized framing and context of Migration Management in the traditional literature. The International Organization for Migration (IOM), in its publication Essentials of Migration Management: A Guide for Policy Makers and Practitioners (2004), indicates a broad 
schematic overview of what falls under the category of Migration Management as follows:

\section{$<$ FIGURE 0.1 HERE $>$}

As can be seen, the categorization of migration issues runs along seemingly coherent lines, and these are now repeated in almost all of the migration studies literature (Mitchell, 1989; Koser, 2007; Castels et al., 2009; Soysal, 1998; Portes, 2007). ${ }^{5}$ Migration Management is defined by Barbara Marshall (2006), in The Politics of Migration - A Survey, as

An initiative to supplement the emphasis on restrictive migration controls by a more constructive approach. For the potential receiving country, it means transparency, i.e. the public acknowledgement of its needs for immigration (demographic developments, lack of skilled and less skilled labour etc.) and its humanitarian obligations. It also involves the integration of legal immigrants. When fully implemented, it would result in 'joined-up government', with all departments making an input into migration policies. Internationally it involves regional co-operation (e.g. in the EU) and with sending countries. (Marshall, 2006: 250)

What this account misses, however, is the logic behind 'restrictive migration control' in the European context and why an emphasis on legal migration is needed - in particular when Marshall in her introduction to the survey also writes that 'illegal migration’ is such a fuzzy concept (Marshall, 2006: 6/7). Academic literature, following deliberations in policy circles, evolved from a discussion about the 'asylum-migration nexus' to research on the 'migration-development nexus'. The former led to a blurring of juridical status concerning migrants, opening the door to a narrative of threat and security regarding asylum seekers and other unwanted migrants. The migration-development nexus in its current meaning offers a way to talk about economic migration when this form of migration had seemed to be discredited in the early 1970s. Juridico-political status, that is legal access, is distributed by Migration Management, which is understood as a discourse grounded 
in the two articulations of security and economy. These work as technologies of citizenship consistent within contemporary ideas of sovereignty allocating places and functions.

Discourse analysis asks questions of the logic of social signification and practice; it 'travers[es] both linguistic and non-linguistic (governmental) practices as well as artefacts' (Huysmans, 2006: 147) - such categories of intelligibility are at the same time possible and impossible. Discourse is thus partial in its ability to fix meaning: it is relational in so far as identities depend on differentiation. In this sense, categories of intelligibility are characterized by a 'surplus of meaning' that can never be fully exhausted by any one specific articulation. Discourse seeks to impose order and closure on a field of meaning, yet the contingency of meaning precludes this possibility from being actualized and, as a result, discourse excludes. Discourse analysis, in short, provides an insight about the formation of knowledge and meaning; yet it does more than that, it also provides the tools for an analysis of how these knowledges sediment into social order - into something understood as 'common sense' - and, as a result, into articulations regarded as depoliticized.

In the context of the task at hand, Migration Management as discourse, as paradigmatic formation, is composed of two normalized, yet contested, articulations. These two articulations are security and economy - they are parts of the 'regime of truth' (Foucault, 1991) that function as the condition of possibility for formulating illegal and legal migration status respectively. These articulations are suffused with power establishing truth, framing and limiting our ability to make meaning in terms of international migration as dangerous and hence in need of being securitized as well as productive and hence being entrepreneurialized. These articulations are themselves 
limited by the sedimentation of the logic of sovereignty disciplining and regulating what is thinkable (Foucault, 1991).

'Security rhetoric defines existential challenges, which endanger the survival of the political order' (Huysmans, 2006: 25). Walker explains that even though the state is no unitary entity 'the security of the state dominates our understanding of what security can be, and whom it can be for [...] because other forms of political community have been rendered almost unthinkable’ (Walker 1990: 6). Contemporary security governance operates through distributing entitlement to protection and legitimating belonging to a group. The development of security knowledge is, as Huysmans explains, 'a political and normative practice of representing policy questions in an existential modality' (Huysmans, 2006: xi).

Thus, security experts are responsible for policing the boundaries over who counts and who is deviant. In this way a domain of insecurity is constructed through the application of technology and technocratic processes. The domain of insecurity makes two kinds of threat intelligible: on the one hand the threat to social cohesion, including cohesiveness of cultural expression, hand in hand with concerns over protecting the system of social security from abuse. On the other hand, it makes the threat of physical harm and instability intelligible by conjuring up militant groups of refugees taking to arms and undermining state security. In the formulation of these internal and external threats at the hand of unwanted migrants, a boundary is drawn in terms of what is thinkable as illegitimate and hence illegal migration.

The availability of technology and the particular threat formulation bring into being a particular subjectivity: the securitized migrant. In turn, the securitized migrant brings into being a particular formulation of insecurity and with this the application of technocratic processes and technologies. A doctrine is formed which normalizes this 
articulation. Yet a discourse focused only on securitization needs to be balanced by a formulation of what it is not - it needs its negative to provide stable meaning.

'Contemporary neoliberal governance operates through isolating and entrepreneurialized responsible units and individuals,' explains Brown (2015: 129) People, in this articulation, are responsible for themselves - the logic with which neoliberal governance regulates is through tasking them 'with discerning and undertaking the correct strategies of self-investment and entrepreneurship for thriving and surviving; it is in this regard a manifestation of human capitalization' (Brown, 2015: 132/3). In this sense, order is established through subjects who are all operating to enhance their competitive positioning and an emphasis on their own capital value (Brown, 2015: 155). Entrepreneurialization is, then, the articulation which makes two kinds of subjects intelligible. On the one hand are those who are identified as problematic for the proper functioning of society, who need to be developed guided by the will to empower (Cruikshank, 1999; 7). On the other hand, it makes those intelligible who can be counted as privileged 'knowledge migrants' - the homo oeconomicus (Brown, 2015: 10) welcome to participate in the global flows of competitiveness irrespective of protected sovereignties.

Securitization and entrepreneurialization as articulations can be found in other domains than international migration - they have wider influence and form elements in what Rancière (2004) calls the age of post-politics. Migration Management stands out as it is the domain where invisibilizing and normalizing these regimes of truth is maybe most unsuccessful. The age of post-politics is an age in which the discourse of global neoliberal consensus is shared by all and in which the idea of equality (as emancipation) is regarded as outdated illusion (in practice, if not in rhetoric). However, this sterile space is not uncontested: it is disrupted by forces such as the 
anti-globalization movement or groups such as 'no one is illegal', but it is also disrupted by reactionary forces through the emergence of the Far Right and religious fundamentalism, as well as the aggressive reassertion of the authoritarian state under the dubious pretext of security (Newman, 2007b). Before focusing on how this sterile space is contested, it is important to ask how it gets normalized and sedimented.

Rancière thinks of this sterile space as social order, employing his idea of 'police order' or la police which is used in the broader Foucaultian sense. He offers the tools to understand the fusion of policing and policy making in this age of post-politics. The role of la police is to ensure - for the sake of the matrix of sovereignty - a smoothly functioning population. It describes the modern art of government - its rationality (Foucault, 1991): everything is included and has a place allocated and distributed. In other words, someone does the allocation over someone else according to doctrine which has sedimented into enforceable norms. In this way la police not only excludes but also at the same time covers up and justifies exclusion.

La Police, then, is involved in the social ordering and defining of what is 'proper'. A knowledge migrant who can join in to our competitive order and has the right portfolio is proper - occupies a legitimate and therefore legal place, the individual has a function. Even the individual identified as a problem but with the capacity for development is legitimate, maybe not to move internationally, but with a proper place and function to improve and empower his or her own community. By contrast there are those defined as deviant and dangerous to this proper order, those who are imagined to pose a threat to community or stability according to the sovereign order and its technologies of government. These are not proper, in the sense of having legitimacy of existence as a globally mobile person; yet they are registered as deviant 
and thus includable in the order of places and functions - if only to stabilize the meaning of those who are legitimate.

The goal of la police is not only to allocate places and function; it is also to ensure stability by eliminating politics - to prevent the active expression of equality by those who have no part in what is counted as belonging to the proper order (Rancière, 1999). Discourses aim at certainty, as explained above. In the effort to fix meaning, and to fix what are intelligible and actionable articulations, discourse excludes what is excessive and beyond positive fixed knowledge. In the case of the two articulations of securitization and entrepreneurialization they overlap and converge at the point where those who are deemed unwilling to take themselves out of their own poverty and misery (Wacquant, 1999, in Huysmans, 2006: 41), but claim the right to international mobility nonetheless, are so radically excluded that they do not count at all. Rancière describes this excess as the 'part that has no part' (1995). The part that has no part is suspended, not only from the proper order, but also from being intelligible.

The dynamics between the norm and deviance are comprehensible through the police order, an order that ensures stability and only allows debate in so far as it stays within the logics of the two articulations. Thus, participating in this order can be claimed, for example through voting or civil society engagement, but it is impotent participation: it is delineated, participants are expected to conform, and exclusion becomes invisible through the stratification of participation (May, 2008; Cruikshank, 1999). Contestation, in the 'proper' order, ends up being a call for passive equality through traditional mechanisms of policing: it makes concessions to those who deviate, in the sense that it offers procedures whereby the consent of collectivities is achieved - the distribution of places and functions (May, 2008: 41). It is in this sense that I speak of Migration Management as contested normalization. 
There is a vast and important literature that can be captured as critical migration studies. It is a literature that destabilizes the polarizing effects of accepting an orthodox understanding of sovereignty and seeks to disarticulate the relationship between state, territory and citizenship as major components of the sovereign matrix (Agnew, 1994; Elden, 2009). It is a literature that argues that international migration as a phenomenon undermines the relationship and makes visible how problematic assumptions of a sovereign order are. More concretely, this literature understands the state as a dynamic construct which needs continuous maintenance and refounding (Amoore, 2006; Coleman, 2007,2009; Gamlen, 2008; Hyndman, 1997, 2012; Mountz, 2010). The critical literature is successful in offering this changed perspective in focusing on particular border technologies (Bigo, 2014; Walters, 2004); or focusing on case examples of particular countries and how their bureaucracy maintains the state amid tension and contradiction (Mountz, 2010; Guild, 2009; Kalyvas, 2002; Doty, 1996); or focusing on the deleterious effects restrictive policies and securitization have on international norms (Doty, 2003; Hyndman, 2000; Huysmans, 2000, Bigo, 2000) or those mobile people in the transnational space (Nadig, 2002; Andersson, 2014); or focusing on the effects on citizenship of both legal and illegal movement into the Global North (Nyers, 2006; De Genova, 2004; Squire, 2014). Yet an inside/outside conceptualization is nonetheless reflected in most of the critical research (Soguk, 1999; Walker, 1993). This is neither surprising nor necessarily detrimental to the important contribution this literature makes to critically appraising the governmental practices of the Global North. In order to problematize aspects of change, for analytical purposes some elements must be kept constant. I want to build on this research by showing how some of the conceptual elements the critical literature keeps constant, or takes for granted, are far from normal; in particular the 
idea of the illegal migrant. Much literature is deeply insightful about how illegality today is reproduced over and over again and with which effects (Squire, 2009) - I want to show how it was possible to construct the illegal and legal migrant in the first place to show that the power effects that follow from this construction mean that everything that follows from and draws on the normalized idea of framing mobility in terms of legal access is perverse and normatively violent.

Understanding a government's perspective (Kuus, 2014; Mountz, 2010) or, rather, seeing like a consortium of states, as in the case of convergence of doctrine among the governments of the Global North, is thus a perspective that needs to be added to the critical literature as it enables us to ask better and more self-critical questions about governing international migration. This also includes a need to look at some of the literature which focuses on international migration framed with problem-solving intent. This literature might end up being complicit in participating in the making of sovereignty-framed knowledge on mobile people (Thielemann and Armstrong, 2013). It is in this respect that it is important to understand Migration Management as a discourse of contested normalization. External migration relations as constructed and enforced by the countries of the Global North today are heavily contested, by civil society organizations, by scholars, by civil servants and by journalists; yet most accept the sovereign framing of migration as a problem and are looking to establish better conditions for mobile people, rather than asking questions about the legitimacy of this sovereign framing.

\section{Conditions of possibility: three crises and a reactionary rupture}


Migration Management is a distinctive treatment of human mobility in that it is largely an expression of European sovereign power which determines access, allocates or denies place, and determines who counts as subject and who does not. This is new in so far as, until the 1970s, the juridical status of an immigrant was epiphenomenal to the social order (Castles and Miller, 2009). Most migrants entering Western European countries were factually illegal by today's standards in that they were without documents. The focus was on either getting manual workers or providing refugees from the communist Other with a new home. The situation of those without legal documentation was remedied once in country and not considered noteworthy. Migrants were functional in the first place, not legal, and they were integrated once they had arrived.

Migration Management as a doctrine to guide knowledge and practices on international migration has normalized since the 1980s, as a result of reactionary ruptures. From the 1980s the categories of intelligibility changed. Understanding the context which led to the rupture of moving out of the multilateral context and to reformulate the doctrinal contours have to be understood.

The 1960s had experienced what Samuel Huntington termed 'democratic distemper' (in Crozier, 1975: 37). Countries of the Atlantic alliance, at the time, perceived of a counterculture of radical opposition (by, for example, women and ethnic minorities): a lack of constraint, lack of respect for authority and the undermining of order. Crozier (1975: 12) identifies two basic characteristics of the fundamental problem that Europe in particular was faced with:

- The European political systems are overloaded with participants and demands, and they have increasing difficulty in mastering the very 
complexity which is the natural result of their economic growth and political development.

- The bureaucratic cohesiveness they have to sustain in order to maintain their capacity to decide and implement tends to foster irresponsibility and the breakdown of consensus, which increase in turn the difficulty of their task.

According to the Crisis of Democracy (1975) Atlantic alliance states (North America, Western Europe and also including Japan) were in danger of becoming ungovernable through democratic overload. Populations, voicing demands for greater equality, rights and participation and more freedom from the state, were asking for too much. The social movements of the 1960s were seen to have posed a considerable challenge to North America and Western Europe. Populations asked not only for welfare for parts of society that had not been seen to be eligible in their own right (such as women having given birth out of wedlock); they were demanding a voice not given to them before (such as the black community and other minority groups). One such struggle was the call from women to gain more freedom, for example with regards to their sexual and reproductive rights, but also on the other hand for government to protect them more actively as individuals, for example vis-à-vis their husbands in cases of domestic violence (Cruikshank, 1999). Minorities demanded equal rights not only with regard to political and civil rights. This 'excess of democracy' (Campbell, 1998: 163) posed a danger for established authorities to being able to act at home and abroad. It was seen to pose a twofold danger, (1) the 'excess' makes demands on being part of policy making and (2) efficiency, not only in economic terms, is endangered by deranged, uneducated and tired migrants (Kaplan, 1994) trying to enter the Global North, and particularly Europe, in an unsolicited way. 
As the crisis of democracy unfolded, another crisis unfolded at the same time: the steering of the domestic economy through different forms of welfare governance which had been established throughout Europe since the Second World War was impacted by the 1970s economic crisis leading to the subsequent abandoning of the Bretton Woods system (Hunt, 1986: 154). This move was explained as being caused by a lack of willingness by member states to enter into monetary-political compromises, especially with regard to a giving up of national freedoms to intervene and thus react to the gap between the value of free market gold and central bank gold. Thus, the crisis of democracy and the breakdown of the economic order meant social democracy became a problem in its expression of sovereign territoriality for the purpose of securing the citizenry.

The institutions and principles aimed at securing democracy, the cultures required to nourish it, the energies needed to animate it, and the citizens practicing, caring for or desiring it - all of these are challenged by neoliberalism's ‘economization' of political life and of other heretofore noneconomic spheres and activities. (Brown, 2015: 17)

Political life became a project of management and technocratic governance.

Meanwhile, the bipolar world order that followed the Second World War had let to proxy wars elsewhere, notably in South East Asia. Robinson (2004) recounts the deep impression the Indochinese refugee crisis had made globally and the changes it brought about for the practices of refugee protection. With a protocol from 1967 the Refugee Convention had been globally extended. By 1979 the asylum system in South East Asia had collapsed. Just under one million refugees from Vietnam, Laos and Cambodia were on the move, in boats, to leave strife and violence behind them. At the same time countries such as Thailand and Malaysia pushed back boats full of people seeking protection from persecution. Many also arrived in Hong Kong, a UK territory at the time. As a result of this situation, governments met in Geneva for a 
conference to find solutions to this asylum crisis at which many of the major donors to the UNHCR agreed to a Comprehensive Plan for Action ${ }^{6}$. In order to secure the right to asylum, the ‘innovation’ made by this plan of action was a compromise: countries in the region would offer temporary asylum supported by financial incentives for the region, while donor countries would offer third-country resettlement, based on regional processing which for the first time also included the option of repatriation, including in the form of forced return.

In addition to receiving resettled Indochinese refugees and asylum seekers from the Middle East and Communist Europe, and based on ever-extending human rights norms, governments of the Global North had to recognize the right to family reunification for those 'guestworkers' who had not returned. The population of Europe grew more diverse as a result, belying the narrative of cultural homogeneity: averaged for the 1980s and across European countries, Asian people accounted for just over 30 per cent of the population seeking protection, whilst the majority, slightly above 40 per cent of asylum seekers, were of European origin (mainly Romanians, Poles and Bulgarians); by contrast asylum seekers from Africa and elsewhere were counted as under 20 per cent according to Boecker and Havinga (1998).

Yet the literature points not only to debates about whether or not there were numerically more refugees and asylum seekers (for example, boat people from South East Asia, refugees arriving through the Mediterranean, and refugees generated by the Iran-Iraq war pose the geopolitical background to discussions in the IGC) than there had been before. ${ }^{7}$ Another, more important argument for Western European governments was that not only issues such as human rights abuses but also economic marginalization, poverty, environmental degradation, population pressure, and poor governance were seen as responsible for increased immigration into Europe (Weiner, 
1995; Hein, 1993, 1995; Suhrke, 1994; Zolberg, 1989). In other words, whilst the refugee and migration literature at that point makes reference to an increasingly interdependent world (Escalona and Black, 1995), it mainly focuses on specific phenomena of reception and integration; it pays little attention to the transnational politics involved in knowledge production of the phenomenon of people mobility. It emphasizes crisis and the lack of control and stability, which demand urgent action. The combination of these ruptures in the 1970s and 1980s frame the conditions of possibility for reactionary rupture that brought the IGC into being. The concern with people mobility and the differentiation between people as either aliens or citizens remained a constant in knowledge production to maintain the police order. The articulations of security and economy, the securitization and entrepreneurialization of international migrants, disrupted an order which had emphasized humanitarianism, protection and the instrumentalization of people for growth and introduced discontinuity. These new articulations began to shift regulation of international migration into the transnational sphere. Thus, these crises accumulated to rupture a presumed stability and produced a particular kind of knowledge that was hoped to bring control, not least by emphasizing ideas of there being different kind of aliens.

\section{Poststructuralism, genealogy and tactical philosophy as anarchist ethics}

The 1980s set a process in train with regard to international migration that would develop into a complete overhaul of the underlying meaning of those concepts which make international migration comprehensible. It therefore fundamentally changed the symbolic order ascribed to migration. I approach the argument of this book and hence the questioning of sovereignty in genealogical fashion. We make knowledges by 
moulding and kneading - we interpret. The perspective that guides the unfolding of my interpretation here is informed by a poststructural understanding of tactical philosophy as anarchist ethics (May, 1994).

Poststructuralism, as I use it here, wants to achieve a thorough disruption of our stable sense of meaning, of the references we make to a fixed order as expressed by discourses: for example by those expressing how international migration is to be regulated. It aims to make power relations legible. It aims to disrupt our understanding of identity as representations which attempt to fix political subjectivities; for example, those expressions which allocate a particular function to the refugee as vulnerable, or the asylum seeker as deviant. It attempts to disrupt our sense of history as linear, progressive development and its role in the present; for example our superiority claims, in the Global North, as 'civilized' societies which function best and most peacefully within a sovereign democratic order of an otherwise potentially barbaric international space. By asking questions about how power circulates and imposes specific knowledges, it guards against the often invisible violence of established values, such as those expressed in commonsense norms, practices and legal frameworks. Poststructuralism thus affirms the productive power effects of limits, such when we have to recognize that international migration cannot be managed tout court, that exclusion is futile, and that such ruptures transform and may act to counter dominance and violence. The approach I am taking here helps me to shows that the production of meaning is only possible against a negative Other; as a differentiating practice, which excludes. The illegal migrant, as will be discussed, concretizes this notion of différance (Deleuze, 1994). A political subjectivity that is temporarily disappeared, one that is suspended. Political subjectivity describes more specifically the process of interaction between discursive 
environment, undecidability and the need to arrive at a decision (Reckwitz, 2006: 346/7). Within the sovereign neoliberal democratic order, the migrant as deviation, as alien, is an expression of political subjectivity imposed in order to stabilize the positive construction of ourselves as civilized, orderly and bounded citizens. My analysis is an intervention into the interstices of articulation that form discourse. Migration Management, for example, articulates essentialized forms of knowledge about international migration. There is the legal migrant, who is entrepreneurial: the knowledge migrant who is allocated the capacity of making a contribution to the neoliberal consensus. His or her negative Other is the illegal migrant, who is allocated no capacity at all, other than either being criminal or vulnerable. What this neat articulation of a seemingly all-encompassing typology misses is the effect of domination, which leads to a further political subjectivity: that of the suspended person. These essentialized forms of knowledge are not representations of positive knowledge; what I am offering is an analysis of those knowledges - power effects with the purpose of offering a critique of domination.

I am as interested in the creativity of power as in its repressive character. As such a focus on practices based on doctrine formed in the 1980s and 1990s constitutes goaldirected social regulation that should not be assumed to be transparent in effects to their actors who engage in doctrine formation (May, 1994). In other words, I do not here assume conscious, positive knowledge on the part of international and national civil servants, experts and other elites. I am assuming that the knowledge drawn on to form doctrine is informed by prejudice, partial knowledge and discursive inflection. It is thinkable, sayable knowledge constructed within a framework of hegemonic 'reality' construction. Poststructuralism assumes that these power effects circulate in such a way that discourses are anonymous; there is no possibility to tell an identity- 
related story that can allocate responsibility. Discourse, Howarth summarizes, 'refers to systems of meaningful practices that form the identities [...] of social relations [...] which involves [exclusions] and always involve[s] the exercise of power' (Howarth, 2000: 3/4). Discourses are contingent and historical. While a discourse is conditioned by the past - the situation in which it arises - and by history - the way in which we narrate the past - it is not determined by past and history. Discourses exceed past and history, leading to the emergence of something transformed. Rancière (2010) tells us that politics is never more or other than a political moment, a political event: as such what is offered here is a political history of the emergence, character and consequences of Migration Management. Politics occurs in history. Knowledge is a matter of struggle and domination.

Traditional history writing represents the passage of time as a logical flow of causally connected events, each of which has significance and forms part of an overall pattern (McNay, 1994). It is a universal explanation indicating unity; this is an erroneous portrayal as macro-consciousness which suppresses alterity to guarantee the coherence of identity. Instead, genealogy is an analysis of the processes that give rise to the emergence of events as discontinuous and divergent - it is knowledge of the past conceptualized as narrative and a perspective which lays bare how this knowledge is used tactically today (McNay, 1994). It is oriented towards the service of life and activity. 'History becomes effective to the degree that it introduces discontinuity into our very being’ (Foucault, translated and quoted Mahon, 1992: 113). Overall, the themes through which we understand our world are products of practices that have as much to do with power as with knowledge; thus genealogy is the study of the (small) practices/events that give rise to the taken-for-granted 'realities' of our society. It is an anonymous play of forces in which the stakes are 
shifting, rather than being unified and constant. The perspective of the genealogist is to present the state of affairs through attention to three interrelated views. First, that which we accept as fact is not the result of meaningful development; rather it is built on the interpretation and reinterpretation of prejudices and value judgements taken as self-evident and/or rationally arrived at. Second, how we perceive our contemporary moment is composed of power effects as power plays out in discourse, in the relationship between truth, theory, values and the social institutions and practices from which they emerge - domination over others leads to differentiation in terms of how identities are represented. Finally, the current state of affairs is based on processes of exclusion which function via strategies of prohibition, division and rejection via the imposition of truth-claims to maintain the integrity of identity, or, in the words of the IGC, the integrity of the system.

The problem then is one of normative violence: the 'particular norms [that] define who is recognizable as a subject capable of living a life that counts' (Lloyd, 2007: 134). The matrix, or normative frame, established by allocation of juridico-political status, establishes the parameters of intelligibility: the citizen, the legitimate migrant, the deviant migrant and the invalid and irredeemable possible-but-not-yet-certain migrant. What is important here is that we are all 'invariably in community' (Butler, 2006:27). However, this being in community requires recognition or nameability, since people's subjecthood is not only socially articulated and placed within a particular order, it is also transformable - in this sense it is a space of vulnerability. As a result, Butler notes, sometimes people are deprived of the possibility of having a status; this Butler describes as the ‘violence of de-realization’ (Butler, 2006:34). Normative violence, then, means that certain people, or groups of people, fail to count 
as human according to the dominant regime of intelligibility, and such intelligibility comes in two forms; as object of prohibition or as erasure. The suspended are erased. I am, thus, offering a history of the present in terms of its past and its violence. It is a history of logical spaces and their succession in time - rather than a causal explanation. Accordingly, I will start from analysing the present and explain the formation of this present in terms of its past through the eyes of the IGC. In this sense, also, genealogy is episodic - it does not aim to describe the past in its entirety; instead the focus is on the episodes, moments and ruptures in the past that are crucial to understanding of what was singled out and emphasized as problematic in the present. When I use the term rupture, I mean to express a break with the existing order in an ontological sense - rupture helps the emergence of a new kind of world through the dynamic interplay of the everydayness of events that are numerous and take many forms. Thus, international migration is made sense of in its relation with, and context of, discourses expressing securitization and entrepreneurialization within the neoliberal consensus. It is not articulated in the context of community, hospitality, or freedom and equality. In my analysis, I will in particular focus on Migration Management's normative violence, the norms which govern the field, to then offer some thoughts about active democracy as practice to counter such violence.

It is for this reason that I argue that sovereignty as an organizing principle is dubious not only practically and empirically, but also theoretically. We cannot logically conceive of a centre within which power resides. The interplay of many sites from which power arises creates the social world as a dynamic, pluralistic web of relationships. In this sense it is not only powerful governmental elites who 'cause' the emergence and enforcement of international migration regulations; statecraft as it pertains to international migration is more dynamic and encompasses people who 
move, international experts on mobility, and mobility controllers as much as mobility facilitators. At the same time as the elements of this plurality try to stabilize to a degree, this interplay has the capacity to rupture the social world as it attempts to totalize into the neoliberal consensus, concretely expressed as Migration Management.

Hence, poststructuralist thought is sceptical about hierarchical conceptions of the world. The exercise of power comes into play in the very constitution of the world. May explains: 'Tactical thought thus performs its analysis within a milieu characterized not only by tension between what is and what ought to be, but also between irreducible but mutually intersecting practices of power' (May, 1994: 11). Yet there are concentrations of power, and I will evaluate one of these instances - the IGC - based on more general considerations of context and ethics as the horizon for evaluation.

The appeal of poststructuralism is its concern for representation and difference. I rephrase here closely Todd May’s arguments in his introduction to Reconsidering Difference (1997). Difference within this perspective is seen to be constitutive of our world, both in terms of sharing with, but also as obsession with, the Other: the migrant and in particular the illegal migrant. Migration Management seeks to eliminate difference by imposing the categories of 'legal' and 'illegal' migrants covering all possible movement. This is an illusion. The capturing of an essence of a matter which cannot be surpassed is not only not possible but also dangerous as it leads to normative violence against those represented as marginalized to the point of suspension. May states

Thinking of community in terms of a common substance that we all must participate in marginalizes those who are different from the participants in that common substance; [...]; thinking of ethics in terms of the likeness or 
analogies of others to oneself refuses the insight that what is ethically relevant is often the difference of others from oneself; thinking of ontology in terms of identity precludes considerations of ontological possibilities that are irreducible to any identity. (May, 1997: 4)

It is in this context that any discursive practice that proclaims itself to be superior and indubitable and assumes power to reside in an essentialized centre - either implicitly or explicitly - needs close scrutiny. Such scrutiny is offered by poststructural anarchism: to enable thinking a horizon (not a singular universalism) of active democracy based on the presupposition of equality.

Why this approach - what do other approaches miss? Liberal approaches to sovereignty and statehood, whether they are liberal-utilitarian, communitarian or cosmopolitan, ask questions about how and to what degree international mobility is allowable and how it should be regulated. As a result this is not a system of absolute sovereignty, but one that legalizes and distributes inclusion and exclusion. Liberal approaches are hierarchical, defining superiority and inferiority and locating exclusion to be the right of the state - coercion is a consequence of the state (Thomas, 2013). Within liberalism, democracy masks a permanent state of insecurity and competition in order to legitimize the state's existence; democracy is representative of a fiction disguising the ordering principles of domination and violence.

By contrast, critical approaches ranging from Marx to Schmitt to Foucault expose the power circulations and the domination infused in liberalism - they ask about the dynamic establishing the justification of the existence of boundaries and therefore, exclusions (Thomas, 2013). This framing exposes - and this is important - the destructive power/knowledge constructions; however, some of these approaches are so distinctly illiberal in consequence that they lack any claim to an open alternative; others do not go beyond the analysis of the conditions of possibility and practices of 
exclusion. Tactical philosophy as anarchist ethics might help to think such going beyond.

Poststructural anarchism is a radical critique of domination; it goes beyond most critical approaches in that it formulates the contrast between exploitation as exclusion and domination (May, 2008). Most critical approaches focus on exploitation as exclusion; however this means that the focus is more often than not on the way in which access and participation are distributed illegitimately for the benefit of some and to the detriment of others, but always within the social order. In order to be excluded, political subjectivity needs to be representable - a person's identity must be intelligible. In these critical approaches the extent of distribution is queried, but this approach assumes that someone does the distribution and someone else accepts the distributing. It leaves the basic logic of the 'alien’ intact, it does not do away with bounded liberal democratic right, and ultimately it does not question the logic of the citizen - in whichever form. In Rancière's terminology, critical approaches focus on the part which has access to something, even if that something is very little and very precarious (Rancière, 2010).

By contrast, injustice is a matter of domination as the hierarchical, authoritarian way of unequally ordering society the impersonal, abstracting and technocratic state denies a person's capacity to participate - actively - in creating a meaningful life in community with others. The sovereign state - however constrained by law - thus both creates and makes invisible the part that has no part, those who are suspended. The poststructural anarchic presupposition of equality proposes instead that each of us is capable of creating - along with others - a meaningful life free of imposition and authoritarian rule (May, 2008; Newman, 2003; Springer, 2011). Equality is a demonstration that we assume, that can only be verified in practice - it is a 'logic that 
calls any system of domination into question' (Chambers, 2013: 29). It neither needs grounding, nor is it in need of justification. 'The essence of equality is not so much to unify as to declassify, to undo the supposed naturalness of orders and replace it with the controversial figures of division' (Rancière, 1995: 32). Underpinning equality is the logic that each person is capable of communicating with another, understanding and reasoning; 'each possesses the quality of being able to consider and act upon our world in such a way as to create a life that has significance’ (May, 2008: 57).

Crucially, such equality must be taken and cannot be given - it cannot be distributed (Rancière, 1995).

\section{De-democratizing moves, normative violence and the geopolitics of migration}

The problem I am posing here is that ideas that were reflected on - the IGC's common conceptual field as it was developed - were not 'oxygenated', they were not aired and discussed openly, but in secret. This is problematic for states that are so vocal about being 'democratic'. The reply to this charge would surely be that participants would bring their ideas back to their national administrations and ministries, and thus ideas were introduced into the national and European democratic and formal processes, and that - anyway - policy making was better kept quiet given the volatile and negative public opinion about migration. Yet, given that most focus, most energy and most resources are directed at external migration relations, the rigidity of this legal order of places and functions, of illegality and legality of access, is exposed. This order, with its particular norm imposition, is dominance amounting to violence in the sense that Butler (1999) conceptualizes it. It is an order bounded by what is discursively intelligible and what is not; it is an order imposing hierarchies of 
meaning delimiting what is thinkable and what is not; it is thus an order prescribing who is of ac/count and who has no part (Rancière, 2001).

This norm establishment is violent precisely because it conceives of itself as giving a status to everyone: recall Rancière's observation above that these days everyone is included - except those who are not allocated a place and a function. Normative violence is violence that is involved in the production of meaning and intelligibility, which works for some meanings to prevail and others to be foreclosed absolutely (Butler, 1991). Norms are about who is superior, who is inferior, and who or what is an object of erasure, that is, not intelligible at all. A suspended person's existence is illegitimate, these people have no meaningful political subjectivity, and hence they disappear from the radars of intelligibility - they are rendered socially dead. In committing such suspension an attempt is made to safeguard the imaginary integrity of the system by using extraterritorial mechanisms of radical exclusion. Yet this exposes the imposition of control as an expression of state power; as such, sovereignty continues to justify 'all that is corrupt, authoritarian and brutal about political regimes’ (Thomas, 2013: 29) like Migration Management.

Simply put, the problem is that the Global North, through its discourse of Migration Management, creates a new world map in redrawing boundaries: the Global North makes policy on the Global South sandwiched in between its edges, as 0.1 and 0.2 illustrate. Migration Management is essentialized into questions of access, it acts on the spaces at the points where the Global North ends, and the Global South is conceptualized as ephemeral, poor and struggling to participate in the neoliberal consensus.

\section{$<$ MAP 0.1 HERE $>$}


Of course, such illustration is crude - the Global South participates in the practices and relationships of the neoliberal consensus. Yet it is no coincidence that Map 0.2 so neatly highlights the overlapping boundaries of countries participating in the doctrine formation of Migration Management that I want to highlight in this book. Those boundaries are geographical in so far as they create spaces in which doctrine formation enables normative violence to too many who are deemed to have lost their validity to exist.

\section{$<$ MAP 0.2 HERE $>$}

Yet those boundaries are also figments of the imagination, as the refugee crisis in 2015 clearly showed: people come anyway. Hence the argument that guides this book is that attempting to manage migration is, futile. Rather, Migration Management is more productively understood as a doctrinal formation, which is de-democratizing and violent, not only in consequence, but at the point of its formation. Migration Management rests on knowledge production embedded in consensus-democracy. Ruptures destabilize the imagined coherence of this transnational policy project, such that moments of equality and active democracy are enacted, and as such rupture makes Migration Management’s domination visible.

In itself this claim is not new. There is a growing critical migration, refugee and border studies literature that makes similar claims as discussed above. Yet not many scholars or practitioners query sovereignty claims and point to the act of violence at the heart of Migration Management which causes not only physical death at the point of policy enforcement, but also - and maybe worse - social death through the very normative and essentializing character of Migration Management. Further, most changes in policy making on international migration are grounded in policy implementation which became visible during the 1990s. In grounding research in 
formal policy making, much of the ideas have circulated, have normalized and sedimented.

\section{Roadmap of the argument}

I want to show how Migration Management came to be possible and what its logic is, in order then to offer an ethico-political evaluation; in this way the book is genealogical in character and offers an ethico-political critique framed within postanarchist thought as outlined above. In what follows I want to to shed light on doctrine formation - the moment when ideas form and are circulated - in order to ask what their conditions of possibility are. The IGC's ideas about how to respond to the 'significant increase in the numbers of asylum seekers and refugees arriving in Europe' (Johnston, 2005) circulated in an effort to construct a common discursive field. IGC participants laid the foundation for what would become the driving logic of Migration Management: in short, the effort to establish policy tools that would regulate people mobility. As this field had become increasingly one of external policy focus it converged to questions of juridico-political status around access.

I aim to emphasize that changes in the conception of cross-border mobility have to be understood in the context of the broader dynamics of the formulation of neoliberalism in the sense that Brown (2015) understands it: a fundamentally different framing of our lived reality as individuals as portfolio-carrying human capital. It is in the context of sovereign and disciplinary power and governmental management that Rancière states: 'Today, all of us are supposed to be "included" in a totality that is defined in consensual terms as an addition of groups each regarded to have its own identity' (Rancière, 2001: 348). All those deemed to be capable of participating in the 
neoliberal consensus have an allocated place, role and function within the neoliberal consensus - and this extends beyond the territorial and increasingly digital boundaries of a particular state; the myth is that no one has been left 'outside'. Yet there are those without juridico-political status. These are the dead bodies found in the sea, but they are also the people who live rough outside the fences the European Union has established around its external borders. However, these few people are so radically excluded that they are not intelligible as persons. Thus states can claim that Migration Management covers all there is to manage about international migration.

Too much of the migration literature focuses narrowly on direct empirical questions such as routes, causes and solutions without taking the bigger conceptual picture into account; or - as in the case of much critical literature - it focuses on the securitizing effects of this new policy, without asking how this logic of illegal and legal migrants came to be possible. Thus, Migration Management is by no means uncontested, but it still functions as the guiding baseline. Research either accepts this - it aims to improve the more deleterious effects - or it criticizes the paradigm and with it policy making for those deleterious effects. The contribution I aim to make is not only to present material that is not available publicly, to offer an alternative understanding of Migration Management and to elaborate what I understand by suspension as a form of political subjectivity; I aim to lay open the conditions of possibility for the construction of the illegal and the legal migrant in the first place to show that the power effects that follow from this construction mean that everything that follows from and draws on the normalized idea of framing mobility in terms of legal access is perverse and normatively violent. In order to do so, the book is organized in three parts. 
Part One, 'Migration Management as normalized but contested discourse’

The first part of the book outlines the logic and composite elements of Migration Management as a discursive formation/paradigmatic guide framing what is intelligible knowledge about migration. It answers the question of what Migration Management is. Chapter 2 discusses how the migration nexuses - the asylum-migration nexus and the migration-development nexus - legitimated the articulation of both the securitized migrant and the entrepreneurialized migrant providing stability to the paradigmatic formation of Migration Management. Chapter 3 shows how the two articulations of Migration Management were operationalized into a typology which acts as guide for policy making and enforcement and allows to claim complete management of migration. Technocracy is the approach which establishes and maintains the 'reasonable order' of sorting everybody into places and functions, claiming to leave no one out. Technocracy turns migrants into sombre things which are managed through sanitized problem solving; this is justified by the logic that anyone who would have to take a decision would be required to come to the same understanding if presented with accurate information - technocracy renders Migration Management inevitable. The purpose of this first part of the book is not to be faithful to all the detailed nuances -these can be found in excellent individual studies on the various components that make up Migration Management. Rather, this part seeks to show the contested normalization of Migration before the rupture brought about by the Middle Eastern refugee crisis of early 2015. I seek to understand Migration Management in its broad contours, as expressed both by the mainstream and by its critical voices. The schematic overview is capable of offering a 'big picture' perspective, which is capable of highlighting Migration Management’s claim to completeness and coherence and thus prepares the ground to theorize Migration Management as an 
ordering device bringing about both social and physical death, giving the lie to any claim on the part of the Global North to being superior either as a society or as implementing an ethically legitimate form of governance.

Part Two The emergence of Migration Management as recorded by the IGC This focuses on the question of what came to pass to make Migration Management. What forces arbitrarily combined to make the IGC and with that the reformulation of regulating the mobility of people globally possible? Chapter 4 highlights the role of three ruptures that took place between the late 1960s and the early 1980s and how the Global North reacted to these ruptures. These crises had a profound effect on how knowledge about the political organization of things is made and what the consequences are for the state, sovereignty and international governance more generally. Chapter 5, accordingly, focuses on how the regulation, or more accurately, the management, of people movement across borders was among the first 'issue' areas to feel the full force of these changes. Rather than the issues raised about international migration being discussed in open multilateral fora, the IGC was established to debate in secrecy and to think up 'solutions' for the problem of mobility into the Global North. Consensus-democracy, the unapologetic abandonment of any pretence to popular participation in standard setting, goes hand in hand with Informal Plurilateralism - a form of international management that has deeply dedemocratizing effects. The geopolitical dynamics of the middle of the twentieth century and the secretive approach taken by the IGC have vastly unacceptable consequences not only for the 3 per cent of the world's population who are on the move, but also for all those who live democratically and largely peacefully, that is, non-violently. Doctrine formation in the context of global mobility took place in the 
IGC, which is of particular interest as it still is a secretive forum, which moulds ideas and articulates truth claims and definitions which are then circulated into the wider group of migrant experts to slowly transform into normalized and sedimented knowledge. What is so problematic is that there is no 'oxygenation' of such articulations, no debate which allows dissensus, since all participants are chosen for their quality of being 'like-minded'.

Part Three Ethico-political evaluation of Migration Management

The premise of this last part is that the principle of democracy cannot be contained within the limits of state sovereignty. If - based on the presupposition of equality everyone has a right to be seen and to be heard, to participate, then this cannot logically - be contained by territorial boundaries. This is something, I contend, that members of the IGC would agree with. However, I come to a very different view of what this premise means. In Chapter 6 I offer a more in-depth look at the effects of the technocracy that is consensus-democracy. It is in the context of consensusdemocracy that international migration is reconceptualized as a question of legal access. Such strategic use of the law produces those without validity to exist. In this system the suspended are not intelligible. Illegal migrants caught in the geopolitical crevasses of internal sovereignty going international are erased - in this way the Global North commits a normative violence so abhorrent precisely because it was not intended. Thus I am showing the 'banality' and the 'evil' that is at the basis of Migration Management. Chapter 7 builds on this ethico-political critique by showing that Migration Management cannot be kept sanitized to such a point that it is immune from dissensus and rupture. On the background of this discussion it is then possible to think about and illustrate how the suspended force recognition of their existence and 
testify to the potential inherent in suspension which is generative.

\section{References}

Agnew, J (1994) The territorial trap: the geographical assumptions of international relations theory Review of international political economy 1(1): 53-80

Amoore, L (2006) Biometric borders: Governing mobilities in the war on terror Political geography 25(3): 336-351

Andersson, R (2014) Illegality, Inc.: clandestine migration and the business of bordering Europe Oakland: University of California Press

Bartelson, J (1995) A genealogy of sovereignty Cambridge: Cambridge University Press

Bigo, D (2000) When two become one: internal and external securitizations in Europe, in M. Kalstrup and M. C. Williams (eds.) International relations theory and the politics of European integration: power, security and community Oxon: Routledge Bigo, D (2014) The (in) securitization practices of the three universes of EU border control: Military/Navy-border guards/police-database analysts Security Dialogue 45(3): 209-225

Böcker, A and T. Havinga (1998) Asylum Migration to the European Union: Patterns of origin and destination Luxembourg: Office for Official Publications of the European Communities

Brown, W (2015) Undoing the Demos - neoliberalism's stealth revolution New York: Zone Books

Butler, J (1991) Imitation and gender Insubordination, in D Fuss (ed) Inside/Out: Lesbian Theories, Gay Theories London: Routledge, pp 13-31

Butler, J (1999) Gender Trouble: Feminism and the Subversion of Identity London: Routledge

Butler, J (2006) Precarious life: The powers of mourning and violence London: Verso

Campbell, D (1998) Writing Security: United States Foreign Policy and the politics of identity Manchester: Manchester University Press

Castles, S and M. J. Miller (2009) The age of migration Basingstoke: Palgrave Chambers, S. A. (2013) The lessons of Rancière Oxford: Oxford University Press

Coleman, M (2007) A geopolitics of engagement: Neoliberalism, the war on terrorism, and the reconfiguration of US immigration enforcement Geopolitics 12(4): 607-634

Coleman, M (2009) What counts as the politics and practice of security, and where? Devolution and immigrant insecurity after 9/11 Annals of the Association of American Geographers 99(5): 904-913 
Crozier, M; S. P. Huntington and J. Watanuki (1975) The Crisis of Democracy: Report on the Governability of Democracies to the Trilateral Commission New York: New York University Press

Cruikshank, B (1999) The will to empower: Democratic citizens and other subjects Cornell University Press

De Genova, N (2004) The legal production of Mexican/migrant "illegality" Latino Studies 2(2): 160-185

Deleuze, G (1994) Difference and repetition Columbia University Press

Doty, R. L. (1996) Imperial encounters: The politics of representation in North-South relations Minneapolis: University of Minnesota Press

Doty, R. L. (2003) Anti-Immigrantism in Western Democracies: Statecraft, desire and the politics of exclusion London: Routledge

Dowty, A (1987) Closed Borders: The contemporary assault on freedom of movement New Haven: Yale University Press

Elden, S (2009) Terror and territory: The spatial extent of sovereignty Minneapolis: University of Minnesota Press

Escalona, A and R. Black (1995) Refugees in Western Europe: bibliographic review and state of the art Journal of Refugee Studies 8(4): 364-389

Foucault, M (1991) Governmentality, in G. Burchell, C. Gordon and P. Miller (eds.) The Foucault Effect: Studies in Governmentality Hemel Hempstead: Harvester Wheatsheaf

Gamlen, A (2008) The emigration state and the modern geopolitical imagination Political Geography 27(8): 840-856

Gibney, M (1988) Open Borders? Closed Societies?: The ethical and political issues New York: Greenwood Press

Guild, E (2009 Security and Migration in the 21st Century Cambridge: Polity Hampshire, J (2016) Speaking with one voice? The European Union's global approach to migration and mobility and the limits of international migration cooperation Journal of Ethnic and Migration Studies 42(4): 571-586

Hein, J (1993) Refugees, Immigrants and the State Annual Review of Sociology 19: 43-59

Hein, J (1995) From Vietnam, Laos and Cambodia: A Refugee Experience in the United States New York: Twayne

Howarth, D and Y. Stavrakakis (2000) Discourse Theory and Political Analysis: Identities, Hegemonies and Social Change Manchester: Manchester University Press Hunt, E. K. (1986) Economics - An Introduction to Traditional and Radical Views New York: Harper \& Row 
Huysmans, J (2000) Contested Community - Migration and the question of the political in the EU, in Morten and Williams (eds.) International Relations Theory and the Politics of European Integration: Power Security and Community London: Routledge

Huysmans, J (2006) The Politics of Insecurity: fear, migration and asylum in the EU London: Routledge

Hyndman, J (1997) Border Crossings Antipode 29(2): 149-176

Hyndman, J (2000) Managing Displacement Refugees and the Politics of Humanitarianism Minneapolis: University of Minnesota Press

Hyndman, J (2012) The geopolitics of migration and mobility Geopolitics 17(2): 243255

IOM (2004) Essentials of Migration Management: A Guide for Policy Makers and Practitioners Geneva: IOM

Kalyvas, A (2002) The Stateless Theory, in S. Aronowitz, and P. Bratsis (eds.)

Paradigm Lost: State Theory Reconsidered Minneapolis: University of Minnesota

Press, pp. 105-142

Kaplan, R. D. (1994) The Coming Anarchy The Atlantic Monthly, Feb issue

Koser, K (2007) International Migration - A very short introduction Oxford: Oxford University Press

Kuus, M (2014) Geopolitics and expertise Malden, MA: Wiley-Blackwell

Marshall, B (ed.) (2006) The Politics of Migration - A Survey London: Routledge

May, T (1994) The political philosophy of poststructuralist anarchism PA: Penn State Press

May, T (1994) The political philosophy of poststructuralist anarchism PA: Penn State Press

May, T (1997) Reconsidering Difference: Nancy, Derrida, Levinas, and Deleuze PA: Penn State Press

May, T (2008) The political thought of Jacques Rancière: Creating equality

Edinburgh: Edinburgh University Press

Mitchell, C (1989) International migration, international relations, and foreign policy International Migration Review 23(3): 681-708

Mountz, A (2010) Seeking asylum: Human smuggling and bureaucracy at the border Minneapolis: University of Minnesota Press

Nadig, A (2002) Human smuggling, national security, and refugee protection Journal of Refugee Studies 15(1): 1-25

Newman, S (2003) Stirner and Foucault: Toward a Post-Kantian Freedom Postmodern Culture 13(2) Retrieved from Project MUSE 
Newman, S (2005) Power and Politics in Poststructural Thought London and New York: Routledge

Newman, S (2007a) Anarchism, poststructuralism and the future of radical politics SubStance 36(2): 3-19

Newman, S (2007b) Unstable Universalities: Poststructuralism and radical politics Manchester University Press

Nyers, P (2006) The accidental citizen: acts of sovereignty and (un) making citizenship Economy and society 35(1): 22-41

Opeskin, B (2012) Managing international migration in Australia: Human rights and the "Last major redoubt of unfettered national sovereignty" International Migration Review 46(3): 551-585

Portes, A (2007) Migration, Development and Segmented Assimilation: A Conceptual Review of the Evidence Annals - American Academy of Political and Social Science 610(1): 73-97

Rancière, J (1995) On the Shores of Politics London: Verso

Rancière, J (1999) Dis-agreement Politics and Philosophy Minneapolis: University of Minnesota Press

Rancière, J (2001) Ten theses on politics Theory and Event 5(3) Retrieved from Project MUSE

Rancière, J (2004) The Politics of Aesthetics: The Distribution of the Sensible London: Continuum

Rancière, J (2010) Dissensus On Politics and Aesthetics London: Continuum Reckwitz, A (2006) Ernesto Laclau: Diskurse, Hegemonien, Antagonismen; in Kultur. Theorien der Gegenwart VS Verlag für Sozialwissenschaften

Robinson, W. C. (2004) The comprehensive plan of action for Indochinese refugees, 1989-1997: Sharing the burden and passing the buck Journal of Refugee Studies 17(3): 319-333

Soguk, N (1999). States and strangers: Refugees and displacements of statecraft Minneapolis: University of Minnesota Press

Soysal, Y. N. (1998) The citizenship debates: A reader Minneapolis: University of Minnesota Press

Springer, S (2011) Violence sits in places? Cultural practice, neoliberal rationalism, and virulent imaginative geographies Political Geography 30(2): 90-98

Squire, V (2009) The Exclusionary Politics of Asylum Basingstoke: Palgrave Macmillan 
Squire, V (2014) Desert 'trash': Posthumanism, border struggles, and humanitarian politics Political Geography 39: 11-21

\section{Suhrke, A (1994) Environmental Degradation and Population Flows Journal of International Affairs 47(2): 473-496}

Thielemann, E and C. Armstrong (2013) Understanding European asylum cooperation under the Schengen/Dublin system: a public goods framework European security 22(2): 148-164

Thomas, C (2013) What Does the Emerging International Law of Migration Mean for Sovereignty Melbourne Journal for International Law 14: 392

Walker, RJB (1990) Security, sovereignty, and the challenge of world politics Alternatives: Global, Local, Political 15(1): 3-27

Walker, RJB (1993) Inside/outside: international relations as political theory Cambridge: Cambridge University Press

Walters, W (2004) Some critical notes on 'governance' Studies in Political Economy 73(2): $25-42$

Weiner, M (1995) The global migration crisis: challenge to states and to human rights New York: HarperCollins

Zolberg, A. R. (1989) The Next Waves: Migration Theory for a Changing World International Migration Review 23(3): 403-430

\footnotetext{
${ }^{1}$ In this discourse the state is 'capable of assimilating political and social differences into one form, held together by an array of analogical relationships which mediates between the universal and the particular, and between subject and object' (Bartelson, 1995: 241). The state is assumed to be a container of power, equally abstracted from the ruler and the ruled.

${ }^{2}$ This is not the once-imagined idea of the homogenous nation-state, rather it is a notion that 'embraces' diversity but seems to have very clear ideas about who can participate in democratic diversity and who poses a threat to such values - the target at this juncture in history seems to be (radicalized) Muslims.

${ }^{3}$ Jonas Widgren was seconded by the Swedish Government to the United Nations High Commissioner for Refugees (UNHCR) during a time, during the late 1970s and early 1980s, when European governments were concerned about the arrival of South East Asian boat people and called for urgent action for dealing with the asylum crisis. As a result of this secondment he formed the IGC, and later the International Centre for Migration Policy Development (ICMPD).

${ }^{4}$ Council of Europe, Ad-Hoc Committee of Experts on the Legal Aspects of Territorial Asylum, Refugees and Stateless Persons (CAHAR), explained in UNHCR document MP/dm-22.5.85, Back up action; see also page 000 of this book.

${ }^{5}$ In recent years, scholarship has developed which follows more critical lines of enquiry of which scholars such as Didier Bigo and Jef Huysmans were among the first; more recently Jennifer Hyndman, Vicky Squire, and others have added their voices. I will draw on these critical voices in my analysis. However, throughout my elaboration of how Migration Management was filled with meaning I will draw on those 'established' scholars who are influential in policy terms. These scholars work in a more positivist-empirical tradition.

${ }^{6}$ http://www.refworld.org/docid/3dda17d84.html [accessed January 2016]

${ }^{7}$ This is incorrect when compared to the number of Europeans being displaced just twenty years before. We are in fact talking about roughly 3 million refugees.
} 